\title{
Hubungan Higiene Penjamah dan Sanitasi Makanan dengan Kontaminasi Bakteri Escherichia Coli pada Makanan Jajanan di Samping SMP N 2 Sukoharjo
}

\section{The Relationship of Food Handlers Hygiene and Sanitation With Escherichia Coli Bacterial Contamination in Snacks Around Sukoharjo State 2 Junior High School.}

\author{
Amyta Zahro Diana ${ }^{1}$, Triyanta $^{2}$, Wartini ${ }^{3}$ \\ Program Studi Kesehatan Masyarakat Universitas Veteran Bangun Nusantara \\ Email : amyta97@gmail.com
}

\begin{abstract}
Snack food is also beneficial to improve the nutritional quality of food consumed. One effort to improve the quality of human resources in groups of school children is to provide nutritious snacks to meet the needs of the body while attending lessons at school. This study aims to determine the relationship of food handlers hygiene and sanitation with Escherichia coli bacterial contamination in snacks around Sukoharjo State 2 Junior High School.

This type of research is quantitative analytic observational with cross sectional approach. The population and sample in this study were all street food vendors at around Sukoharjo State 2 Junior High School as many as 30 street food vendors. The independent variable is the hand hygiene and food sanitation with the dependent variable is the contamination of Escherichia coli bacteria in the food of snacks. The instrument used was in the form of a checklist sheet, data analysis used the chi-square test and the error rate $\alpha=$ $5 \%$ or 0.05 .

The results showed that the hygiene of food handlers who did not meet the requirements $(56.7 \%)$, sanitation of food that did not meet the requirements $(50 \%)$ and contamination of Escherichia coli in the food snacks $(43.3 \%)$. There is a relationship between hand hygiene $(p=0.007)$, and there is a relationship between food sanitation ( $p=$ 0.001) with Escherichia coli contamination on snacks with a strong enough relationship strength.

It is recommended that the village office, public health center and related health services can provide counseling so that the food and drinks sold are not contaminated with bacteria and are safe for consumption.
\end{abstract}

Keywords: Hygiene, Sanitation, Escherichia Coli Contamination, Snack Food.

\begin{abstract}
ABSTRAK
Makanan jajanan juga bermanfaat terhadap peningkatan mutu gizi makanan yang dikonsumsi. Salah satu upaya meningkatkan kualitas sumber daya manusia pada kelompok anak-anak sekolah adalah dengan menyediakan makanan jajanan yang bergizi guna memenuhi kebutuhan tubuh selama di sekolah. Penelitian ini bertujuan untuk mengetahui hubungan higiene penjamah dan sanitasi makanan dengan kontaminasi bakteri Escherichia coli pada makanan jajanan di sekitar SMP N 2 Sukoharjo.

Jenis penelitian yaitu observasional bersifat analitik kuantitatif dengan pendekatan Cross sectional. Populasi dan sampel dalam penelitian ini adalah seluruh pedagang
\end{abstract}


makanan jajanan di Sekitar SMP N 2 Sukoharjo sebanyak 30 pedagang makanan jajanan. Variabel bebas yaitu higiene penjamah dan sanitasi makanan dengan variabel terikatnya adalah kontaminasi bakteri Escherichia coli pada makanan jajanan. Instrumen yang digunakan berbentuk lembar checklist, analisa data menggunakan uji chi-square dan derajad kesalahan $\alpha=5 \%$ atau 0,05 .

Hasil penelitian menunjukkan bahwa higiene penjamah pedagang makanan jajanan yang tidak memenuhi syarat sebanyak $(56,7 \%)$, sanitasi makanan yang tidak memenuhi syarat sebanyak (50\%) serta kontaminasi Escherichia coli pada makanan jajanan sebanyak $(43,3 \%)$. Terdapat hubungan antara higiene penjamah $(\mathrm{p}=0,007)$, dan terdapat hubungan antara sanitasi makanan $(\mathrm{p}=0,001)$ dengan kontaminasi Escherichia coli pada makanan jajanan dengan kekuatan hubungan cukup kuat. Disarankan pihak kelurahan, puskesmas dan dinas kesehatan yang terkait dapat mengadakan penyuluhan supaya makanan dan minuman yang dijual tidak terkontaminasi bakteri dan aman untuk dikonsumsi.

Kata kunci : Higiene, Sanitasi, Kontaminasi Escherichia Coli, Makanan Jajanan.

\section{PENDAHULUAN}

Makanan merupakan salah satu kebutuhan dasar manusia. Dalam kehidupan seharihari manusia tidak terlepas dari makanan. Sebagai kebutuhan dasar makanan tersebut harus mengandung zat gizi untuk dapat memenuhi fungsinya dan aman dikonsumsi karena makanan yang tidak aman dapat menimbulkan gangguan kesehatan bahkan keracunan. ${ }^{1}$

Makanan jajanan juga bermanfaat terhadap peningkatan mutu gizi makanan yang dikonsumsi. Salah satu upaya meningkatkan kualitas sumber daya manusia pada kelompok anak-anak sekolah adalah dengan menyediakan makanan jajanan yang bergizi guna memenuhi kebutuhan tubuh selama mengukuti pelajaran di sekolah. Makanan jajanan memberikan kontribusi masing-masing sebesar 22,9\% dan 15,9\%, terhadap keseluruhan asupan energy dan protein. ${ }^{2}$

Masalah higiene sanitasi makanan merupakan masalah yang sangat komplek dan sebenarnya bukan menjadi masalah yang baru. World Health Organization (WHO), menyimpulkan bahwa sekitar 30\% dilaporkan keracunan makanan untuk kawasan Eropa terjadi pada rumah-rumah pribadi akibat tidak memperhatikan higiene dan sanitasi makanan. Menurut WHO, di Amerika Serikat saja setiap tahunnya ada 76 juta kasus penyakit bawaan makanan menyebabkan 325.000 jiwa rawat inap dan 5.000 kematian. Sekitar 70\% kasus keracunan makanan di dunia disebabkan oleh makanan siap santap yaitu makanan yang sudah diolah, terutama oleh usaha catering, rumah makan, kantin maupun makanan jajanan. ${ }^{3}$

Kecamatan Sukoharjo menduduki peringkat teratas dalam kasus diare menurut rekapitulasi dari bulan Januari - Desember tahun 2018 dari 94.082 jiwa penduduk 3493 terserang diare. ${ }^{4}$ Berdasarkan hasil survai awal atau pendahuluan yang dilakukan pada tanggal 19 juni 2019 di Sekitar SMP N 2 Sukoharjo menunjukkan bahwa tiga (sempol, cimol dan milung) dari lima sampel makanan jajanan yang di uji positif mengandung bakteri Escherichia coli atau sebesar 60\% mengandung bakteri Escherichia coli.

Menurut survai awal pada bulan juni 2019, 5 dari 10 pedagang yang di observasi pedagang makanan jajanan yang tidak memperhatikan higiene penjamah dan sanitasi makanan seperti pedagang saat melayani tidak memakai celemek dan menangani makanan dengan langsung menggunakan tangan tidak menggunakan sarung tangan plastik dan sanitasi dalam penyajian makanan masih dibiarkan terbuka dari wadah makanannya. 


\section{METODE PENELITIAN}

Jenis penelitian yang digunakan adalah penelitian observasional analitik dengan pendekatan Cross-sectional. Penelitian ini dilakukan di Sekitar SMP N 2 Sukoharjo pada bulan Oktober 2019. Populasinya seluruh pedagang makanan jajanan di Sekitar SMP N 2 Sukoharjo dan sampel penelitian sebanyak 30 pedagang makanan jajanan, dengan teknik sampling total sampling, karena jumlah populasi sama dengan jumlah sampel. Variabel bebas dalam penelitian ini adalah Higiene penjamah dan sanitasi makanan. Variabel terikatnya adalah Kontaminasi bakteri Escherichia coli pada makanan jajanan di makanan jajanan Sekitar SMP N 2 Sukoharjo. Analisis data yang digunakan dengan uji Chi-square dengan $\alpha=0,05$.

\section{HASIL DAN PEMBAHASAN}

Pedagang Makanan jajanan ini terletak di Sepanjang Jalan Harjodiningrat, Pedagang makanan ini termasuk pedagang keliling yang setiap hari mangkal di Samping SMP N 2 Sukoharjo. Kondisi geografis berupa daratan rendah dan berada di jalan yang ramai dilalui banyak orang, sehingga mudah dijangkau dengan kendaraan apa saja.

Kondisi lingkungan di sekitar lokasi penelitian yang sangat memprihatikan dan jauh dari kata layak seperti selokan yang banyak sampah serta tidak terawat dan menimbulkan aroma tidak sedap karena saluran air buangan yang terbuka di samping lokasi penelitian. Tidak ada air bersih yang mengalir

\section{Analisis Univariat}

\section{Higiene penjamah}

Hasil distribusi frekuensi higiene penjamah di Sekitar SMP N 2 Sukoharjo dapat dilihat pada tabel di bawah ini:

Tabel 1. Distribusi frekuensi Higiene penjamah di Sekitar SMP N 2 Sukoharjo

\begin{tabular}{cccc}
\hline No. & Higiene penjamah & Frekuensi & Prosentase \\
\hline 1 & Tidak Memenuhi Syarat & 17 & $56,7 \%$ \\
2 & Memenuhi Syarat & 13 & $43,3 \%$ \\
\hline & Jumlah & $\mathbf{3 0}$ & $\mathbf{1 0 0 \%}$ \\
\hline
\end{tabular}

Sumber : Data primer diolah, 2019

Berdasarkan tabel 1. menunjukkan bahwa 30 orang pedagang makanan jajanan didapatkan hasil sebanyak 56,7\% atau 17 pedagang dikategorikan tidak memenuhi syarat higiene penjamah dan sebanyak 43,3\% atau 13 pedagang memenuhi syarat higiene penjamah.

Dari data distribusi frekuensi higiene penjamah menunjukkan bahwa sebagian besar pedagang atau sebanyak $11(64,7 \%)$ pedagang memiliki higiene penjamah yang tidak memenuhi syarat yaitu $60 \%$ atau sebanyak 18 pedagang tidak memakai celemek dan tidak menggunakan sarung tangan plastik atau saat menangani makanan langsung kontak dengan tangan saat berjualan.

Selain itu $80 \%$ atau 24 pedagang tidak melakukan kebiasaan cuci tangan ketika akan menangani makanan, masih ada $20 \%$ atau sebanyak 6 pedagang laki laki yang merokok saat melayani pembeli dan semua pedagang laki laki tidak mengenakan penutup kepala. Hal ini bisa terjadi kontaminasi silang apabila dibiarkan dalam proses memasak. 


\section{Sanitasi Makanan}

Distribusi hasil penelitian sanitasi makanan di Sekitar SMP N 2 Sukoharjo dapat dilihat pada tabel di bawah ini:

Tabel 2. Distribusi frekuensi Sanitasi Makanan di Sekitar SMP N 2 Sukoharjo

\begin{tabular}{cccc}
\hline No. & Sanitasi Makanan & Frekuensi & Prosentase \\
\hline 1 & Tidak Memenuhi Syarat & 15 & $50 \%$ \\
2 & Memenuhi Syarat & 15 & $50 \%$ \\
\hline \multicolumn{2}{c}{ Jumlah } & $\mathbf{3 0}$ & $\mathbf{1 0 0 \%}$ \\
\hline
\end{tabular}

Sumber : Data primer diolah, 2019

Berdasarkan tabel 2. Menunjukkan dari 30 pedagang makanan jajanan didapatkan hasil bahwa sebanyak 50\% atau sebanyak 15 pedagang tidak memenuhi syarat sanitasi makanan dan hanya $50 \%$ atau 15 pedagang yang memenuhi syarat sanitasi makanan.

Dalam penyajian makanan hampir $43,3 \%$ atau sebanyak 13 pedagang makanan jajanan tidak disajikan pada tempat yang bersih dana man bagi kesehatan karena masih banyak ditemui vektor berupa lalat, dan cara penyajian makanannya tidak di tutupi sebagaimana mestinya atau hanya di biarkan secara terbuka.

Hal ini sesuai dengan prinsip sanitasi makanan jajanan menurut Depkes RI No. 942/ Menkes/ SK/ VII/ 2003 Tentang Pedoman Persyaratan Hygiene Sanitasi Makanan Jajanan yang sesuai yaitu makanan jajanan yang dijajakan harus dalam keadaan terbungkus dan atau tertutup. Pembungkus yang digunakan dan atau tutup makanan jajanan harus dalam keadaan bersih dan tidak mencemari makanan. Pembungkus makanan jajanan yang akan disajikan atau dijual dilarang ditiup. Makanan jajanan yang diangkut, harus dalam keadaan tertutup atau terbungkus dan dalam wadah yang bersih. ${ }^{5}$

Hal ini dapat mangakibatkan Kontaminasi silang dapat terjadi selama makanan ada dalam tahap persiapan, pengolahan, pemasakan ataupun penyajian. Dalam hal terjadinya kontaminasi makanan, sanitasi memegang dua peran yang sangat penting yaitu mengatasi permasalahan terjadinya kontaminasi langsung dan mencegah terjadinya kontaminasi silang selama penangganan makanan. ${ }^{6}$

\section{Kontaminasi Escherichia coli Pada Makanan Jajanan}

Distribusi hasil penelitian kontaminasi Escherichia coli pada makanan jajanan di Sekitar SMP N 2 Sukoharjo dapat dilihat pada tabel di bawah ini:

Tabel 3. Distribusi frekuensi Kontaminasi Escherichia coli di Wilayah Samping SMP N 2 Sukoharjo

\begin{tabular}{cccc}
\hline No. & Kontaminasi Escherichia coli & Frekuensi & Prosentase \\
\hline 1 & Tidak Memenuhi Syarat & 13 & $43,3 \%$ \\
2 & Memenuhi Syarat & 17 & $56,7 \%$ \\
\hline & Jumlah & $\mathbf{3 0}$ & $\mathbf{1 0 0 \%}$ \\
\hline
\end{tabular}

Sumber : Data primer diolah, 2019

Berdasarkan tabel 3. Hasil pemeriksaan kontaminasi Escherichia coli dari 30 sampel makanan jajanan didapatkan hasil bahwa sebanyak 43,3\% atau 13 sampel jajanan makanan positif bakteri Escherichia coli sehingga tidak memenuhi syarat dan sebesar 56,7\% atau sebanyak 17 sampel jajanan makanan negatif bakteri Escherichia coli besar makanan jajanan memenuhi syarat.

\section{Pengukuran Suhu dan Kelembaban}

Hasil pengukuran rata rata suhu dan kelembaban saat dilakukan pengambilan sampel makanan jajanan disetiap slot pedagang makanan jajanan di lokasi penelitian. Berdasarkan data pengukuran suhu dan kelembaban tersebut menunjukkan bahwa suhu 
terendah $23,2^{\circ} \mathrm{C}$ dan kelembaban $53 \%$. Escherichia coli dapat tumbuh pada temperatur $7^{\circ} \mathrm{C}$ sampai dengan $50^{\circ} \mathrm{C}$ dengan suhu pertumbuhan optimum adalah $37^{\circ} \mathrm{C}$.

\section{Analisis Bivariat}

Analisis bivariat adalah analisis yang melibatkan dua variabel, dilakukan untuk mengetahui ada tidaknya hubungan antara higiene penjamah dan sanitasi makanan dengan kontaminasi Escherichia coli. metode statistik yang digunakan adalah uji Chi-Square dengan korelasi koefisien kontingensi.

\section{Hubungan Antara Higiene penjamah Dengan Kontaminasi Escherichia coli Pada Makanan Jajanan}

Tabel 4. Tabel Silang Hubungan Antara Higiene penjamah Dengan Kontaminasi Escherichia coli Pada makanan jajanan

\begin{tabular}{|c|c|c|c|c|c|c|c|c|}
\hline \multirow{3}{*}{$\begin{array}{l}\text { Higiene } \\
\text { Penjamah }\end{array}$} & \multicolumn{4}{|c|}{$\begin{array}{c}\text { Kontaminasi Escherichia } \\
\text { Coli }\end{array}$} & & & \multirow[b]{2}{*}{$p$-value } & \multirow[b]{2}{*}{$\mathrm{C}$} \\
\hline & \multicolumn{2}{|c|}{$\begin{array}{c}\text { Tidak } \\
\text { Memenuhi } \\
\text { Syarat } \\
\end{array}$} & \multicolumn{2}{|c|}{$\begin{array}{l}\text { Memenuhi } \\
\text { Syarat }\end{array}$} & \multicolumn{2}{|c|}{ Total } & & \\
\hline & $\mathrm{N}$ & $\%$ & $\mathrm{~N}$ & $\%$ & $\mathrm{~N}$ & $\%$ & & \\
\hline $\begin{array}{l}\text { Tidak } \\
\text { Memenuhi }\end{array}$ & 11 & 64,7 & 6 & 35,3 & 17 & 100 & & \\
\hline $\begin{array}{l}\text { Syarat } \\
\text { Memenuhi } \\
\text { Syarat }\end{array}$ & 2 & 15,4 & 11 & 84,6 & 13 & 100 & 0,007 & 0,442 \\
\hline Jumlah & 13 & 43,3 & 17 & 56,7 & 30 & 100 & & \\
\hline
\end{tabular}

Berdasarkan tabel 4. di atas menunjukkan hasil analisis hubungan antara higiene penjamah dengan kontaminasi Escherichia coli pada makanan jajanan di Sekitar SMP N 2 Sukoharjo dari 17 pedagang yang tidak memenuhi syarat higiene penjamah, terdapat 11 pedagang atau sebesar $64,7 \%$ ada kontaminasi Escherichia coli pada makanan jajanan, kemudian dari 13 pedagang makanan jajanan yang memenuhi syarat higiene penjamah, ada 11 pedagang atau sebesar 84,6\% tidak ada kontaminasi Escherichia coli pada makanan jajanan.

Hasil uji statistik Chi-square di dapatkan nilai p-value sebesar 0,007, karena nilai $\mathrm{p}$ $<0,05$ maka $\mathrm{H}_{0}$ ditolak dan $\mathrm{H}_{\mathrm{a}}$ diterima, dengan demikian dapat disimpulkan bahwa ada hubungan yang signifikan antara higiene penjamah dan kontaminasi Escherichia coli pada makanan jajanan di Sekitar SMP N 2 Sukoharjo. Hasil analisis Coefisien Contingensi (C) sebesar 0,442 menunjukkan bahwa tingkat hubungan kedua variabel termasuk dalam kategori cukup kuat.

Hasil pemeriksaan laboratorium terhadap 30 makanan jajanan di Sekitar SMP N 2 Sukoharjo menunjukkan bahwa sebanyak 13 makanan jajanan (43,3\%) positif terkontaminasi Escherichia coli, sedangkan 17 makanan jajanan (56,7\%) tidak ada kontaminasi Escherichia coli. Banyaknya makanan jajanan yang terkontaminasi Escherichia coli disebabkan karena $60 \%$ atau sebanyak 18 pedagang yang tidak memakai sarung tangan plastik atau penjepit makanan ketika menangani makanan, masih ada pedagang yang merokok saat melayani pembeli, 20\% atau sebanyak 6 pedagang yang tidak menggunakan penutup kepala, $60 \%$ atau sebanyak 18 pedagang tidak memakai celemek saat berjualan Kebiasaan tidak mencuci tangan terlebih dahulu setelah melakukan aktivitas dan langsung melayani pembeli. Selain itu sanitasi makanan dan dari faktor peralatan yang 
tidak memehuni syarat juga menyebabkan terkontaminasinya Escherichia coli pada makanan jajanan.

Hasil analisis uji Chi square di dapatkan p value $=0,007$ menunjukkan adanya hubungan yang signifikan antara higiene penjamah dengan kontaminasi Escherichia coli dengan tingkat keeratan 0,442. Distribusi silang ini secara deskriptif menunjukkan bahwa frekuensi higiene penjamah mempengaruhi kontaminasi Escherichia coli, semakin rendahnya higiene penjamah pedagang maka semakin tinggi pula peluang makanan terkontaminasi bakteri Escherichia coli.

Hasil penelitian ini sama dengan penelitian yang dilakukan Atmiati, 2012 yang berjudul Faktor-faktor yang berhubungan dengan keberadaan bakteri Escherichia Coli pada jajanan es buah yang dijual di Sekitar Pusat Kota Temanggung, yang mendapatkan nilai $\mathrm{p}$ value $>0,05$ pada variabel higiene penjamah pedagang yang berarti ada hubungan antara higiene penjamah dengan keberadaan Escherichia Coli pada es buah di Sekitar Pusat Kota Temanggung. ${ }^{7}$

Pencemaran atau kontaminasi Escherichia Coli pada makanan jajanan disebabkan dari pedagang yang memiliki higiene penjamah yang tidak memenuhi syarat seperti tidak memakai celemek saat berjualan, tidak menggunakan sarung tangan plastik atau saat menangani makanan langsung kontak dengan tangan. Kebiasaan tidak melakukan cuci tangan ketika akan menangani makanan, dan masih banyak pedagang yang berbicara saat menangani makanan. Masih di temukannya pedagang laki laki yang merokok saat melayani makanan.

Escherichia coli adalah contoh bakteri yang dapat mencemari makanan jajanan. Infeksi dari kedua bakteri ini dapat menyebabkan diare akut yang dapat membahayakan jiwa anak. Escherichia coli juga menyebabkan hemoragik akut akibat proses pematangan makanan cepat saji yang tidak sempurna dan proses pembekuan daging yang tidak optimal. $^{8}$

\section{Hubungan Sanitasi Makanan Dengan Kontaminasi Escherichia coli Pada Makanan Jajanan}

Tabel 5. Tabel Silang Hubungan Antara Sanitasi Makanan Dengan Kontaminasi Escherichia coli Pada makanan jajanan

\begin{tabular}{|c|c|c|c|c|c|c|c|c|}
\hline \multirow{3}{*}{$\begin{array}{l}\text { Sanitasi } \\
\text { Makanan }\end{array}$} & \multicolumn{4}{|c|}{$\begin{array}{c}\text { Kontaminasi Escherichia } \\
\text { Coli }\end{array}$} & & & \multirow{3}{*}{ p-value } & \multirow{3}{*}{$\mathrm{C}$} \\
\hline & \multicolumn{2}{|c|}{$\begin{array}{c}\text { Tidak } \\
\text { Memenuhi } \\
\text { Syarat }\end{array}$} & \multicolumn{2}{|c|}{$\begin{array}{l}\text { Memenuhi } \\
\text { Syarat }\end{array}$} & & & & \\
\hline & $\mathrm{N}$ & $\%$ & $\mathrm{~N}$ & $\%$ & $\mathrm{~N}$ & $\%$ & & \\
\hline Tidak Memenuhi Syarat & 11 & 73,3 & 4 & 26,7 & 15 & 100 & & \\
\hline Memenuhi Syarat & 2 & 13,3 & 13 & 86,7 & 15 & 100 & 0,001 & 0,518 \\
\hline Jumlah & 13 & 43,3 & 17 & 56,7 & 30 & 100 & & \\
\hline
\end{tabular}

Sumber : Olah data SPSS

Berdasarkan tabel 5. di atas menunjukkan hasil analisis hubungan antara higiene penjamah dengan kontaminasi Escherichia coli pada makanan jajanan di Sekitar SMP N 2 Sukoharjo dari 15 pedagang yang tidak memenuhi syarat sanitasi makanan, terdapat 11 pedagang atau sebesar 73,3\% ada kontaminasi Escherichia coli pada makanan jajanan, kemudian dari 15 pedagang makanan jajanan yang memenuhi syarat ada 13 pedagang atau sebesar $86,7 \%$ tidak ada kontaminasi Escherichia coli pada makanan jajanan. 
Hasil uji statistik Chi-square di dapatkan nilai p-value sebesar 0,001 , karena nilai $\mathrm{p}$ $<0,05$ maka $\mathrm{H}_{0}$ ditolak dan $\mathrm{H}_{\mathrm{a}}$ diterima, dengan demikian dapat disimpulkan bahwa ada hubungan yang signifikan antara sanitasi makanan dan kontaminasi Escherichia coli pada makanan jajanan di Sekitar SMP N 2 Sukoharjo. Hasil analisis Coefisien Contingensi (C) sebesar 0,518 menunjukkan bahwa tingkat hubungan kedua variabel termasuk dalam kategori cukup kuat. Distribusi silang ini secara deskriptif menunjukkan bahwa frekuensi sanitasi makanan mempengaruhi kontaminasi Escherichia coli, semakin rendahnya sanitasi makanan maka semakin tinggi pula peluang makanan terkontaminasi bakteri Escherichia coli.

Hasil penelitian ini sama dengan penelitian Hidayat, 2010 yang berjudul hubungan pengetahuan dan praktik penjamah makanan mengenai higiene sanitasi makanan dengan keberadaan Escherichia coli pada nasi rames (studi pada kantin di Lingkungan Universitas Diponegoro Tembalang) yang mendapatkan nilai $\mathrm{p}$ value $=0,005$ pada sanitasi makanan dengan keberadaan Escherichia Coli pada nasi rames kantin di Lingkungan Universitas Diponegoro Tembalang. ${ }^{9}$

Hal ini sejalan dengan penelitian Agus Riyanto dan Asep Dian Abdillah, 2012 yang berjudul Faktor yang mempengaruhi kandungan Escherichia Coli makanan jajanan SD di wilayah Cimahi Selatan yang menunjukkan hasil terdapat hubungan bermakna antara peralatan dan Escherichia Coli makanan jajanan SD (p=0,002). Peralatan makanan pedagang yang tidak memenuhi syarat mempunyai risiko 4,5 kali makanan jajanan yang dijual mengandung Escherichia Coli dibandingkan dengan peralatan makanan pedagang yang memenuhi syarat, setelah dikontrol variabel kebersihan orang pengolah makanan, bahan makanan, dan sarana penjualan makanan. ${ }^{10}$

\section{KESIMPULAN}

Higiene penjamah di Sekitar SMP N 2 Sukoharjo sebagian besar tidak memenuhi syarat yaitu sebanyak $17(56,7 \%)$. Sanitasi makanan di Sekitar SMP N 2 Sukoharjo sebagian besar tidak memenuhi syarat yaitu sebanyak 15 (50\%). Kontaminasi Escherichia coli pada makanan jajanan di Sekitar SMP N 2 Sukoharjo sebagian besar tidak memenuhi syarat yaitu sebanyak $13(43,3 \%)$. Ada hubungan antara higiene penjamah dengan kontaminasi Escherichia coli di Sekitar SMP N 2 Sukoharjo $(\mathrm{p}=0,007$ dengan tingkat keeratan hubungan termasuk cukup kuat $(C=0,442)$. Ada hubungan antara sanitasi makanan dengan kontaminasi Escherichia coli di Sekitar SMP N 2 Sukoharjo $(\mathrm{p}=0,001)$ dengan tingkat keeratan hubungan termasuk cukup kuat $(C=0,518)$.

\section{SARAN}

Bagi Dinas Kesehatan Sukoharjo diharapkan dapat meningkatkan pengawasan secara berkala memberikan sosialisasi mengenai higiene dan sanitasi kepada seluruh pedagang makanan jajanan khususnya wilayah Sukoharjo. Untuk Puskesmas Sukoharjo harus melakukan pengawasan tentang higiene penjamah dan sanitasi pada pedagang makanan jajanan di wilayah sukoharjo. Dapat memberikan tambahan referensi mengenai penelitian yang serupa dan bisa memberikan upaya promotif tentang higiene sanitasi makanan untuk mencegah terjadinya kontaminasi silang. Bagi Pedagang Makanan Jajanan dapat melaksanakan higiene dan sanitasi seperti memakai celemek saat berjualan, memakai penjapit makanan atau memakai sarung tangan plastik, menggunakan penutup kepala agar rambut tidak masuk kedalam makanan, dan tidak merokok pada saat berjualan supaya tidak terkontaminasi bakteri dan aman untuk dikonsusmsi. Masyarakat harus lebih teliti memilih makanan yang akan dikonsumsi karena makanan yang terlihat menarik belum tentu aman dikonsumsi. 


\section{DAFTAR PUSTAKA}

Kemenkes RI. 2012. Kumpulan Modul Kursus Higiene Sanitasi Makanan dan Minuman. Jakarta: Direktorat Jenderal PP dan PL.

Rahmi AA. Muis SF. 2005. Pengaruh Penjamah Makanan Terhadap Kandungan Bakteriologis Makanan Jajanan Di Area Kampus Universitas Indonesia, Jakarta: Universitas Indonesia.

Depkes RI. 2000. Prinsip-prinsip higiene dan sanitasi makanan. Akademi Gizi, Semarang.

Dinas Kesehatan Kabupaten Sukoharjo. 2018. Profil Kesehatan Kabupaten Sukoharjo Tahun 2017. Sukoharjo: Dinas Kesehatan Kabupaten Sukoharjo.

Depkes. 2003. Keputusan Menteri Kesehatan Republik Indonesia Nomor 942/Menkes/SK/VII/2003 tentang Pedoman Pesyaratan Higiene dan Sanitasi Makanan Jajanan. Jakarta: Depkes RI.

Arisman. 2009. Buku Ajar Ilmu Gizi Keracunan Makanan. Jakarta: EGC.

Atmiati, Dwi Wahyu. 2012. Faktor-Faktor Yang Berhubungan Dengan Keberadaan Escherichia Coli Pada Jajanan Es Buah Yang Dijual Di Sekitar Pusat Kota Temanggung, Semarang : UNDIP.

Puspitosari, R.L. 2013. Higiene Makanan, Denpasar: Udayana University Press.

Hidayat, Hanif Amalia. 2010. Hubungan Pengetahuan Dan Praktik Penjamah Makanan Mengenai Higiene Sanitasi Makanan Dengan Keberadaan Escherichia Coli Pada Nasi Rames (Studi Pada Kantin Di Lingkungan Universitas Diponegoro Tembalang), Semarang: UNDIP.

Agus Riyanto, Asep Dian Abdillah. 2012. Faktor Yang Mempengaruhi Kandungan E.Coli Makanan Jajanan Sd Di Wilayah Cimahi Selatan. Stikes Jendral Ahmad Yani : Cimahi. 